\title{
Fears surface over methane leaks
}

\begin{abstract}
Preliminary data from two Arctic cruises suggest that rising temperatures are already causing substantial amounts of methane to be released from beneath the ocean floor. But catastrophic gas leaks, like those believed to have occurred 55 million years ago, are unlikely, scientists say.
\end{abstract}

In the past few weeks, scientists aboard the British research ship James Clark Ross have discovered more than 250 plumes of methane bubbling up along the continental margin northwest of Svalbard. The findings add to a similar discovery by a Russian team in August, that reported elevated methane concentrations near the Lena River delta, as part of the International Siberian Shelf Study (ISSS).

The findings have provoked alarmist media reports predicting massive methane bursts that could accelerate global warming. Methane is a far more powerful greenhouse gas than carbon dioxide, although it is present in much lower concentrations in the atmosphere.

But the phenomenon is probably not new. The scientists believe that methane has been released in the region for at least 15,000 years. "What we're now seeing certainly did not start in the last year or so," says geophysicist Graham Westbrook of the University of Birmingham, UK, who led the British team.

"We have observed increased methane concentrations in the Laptev Sea during several

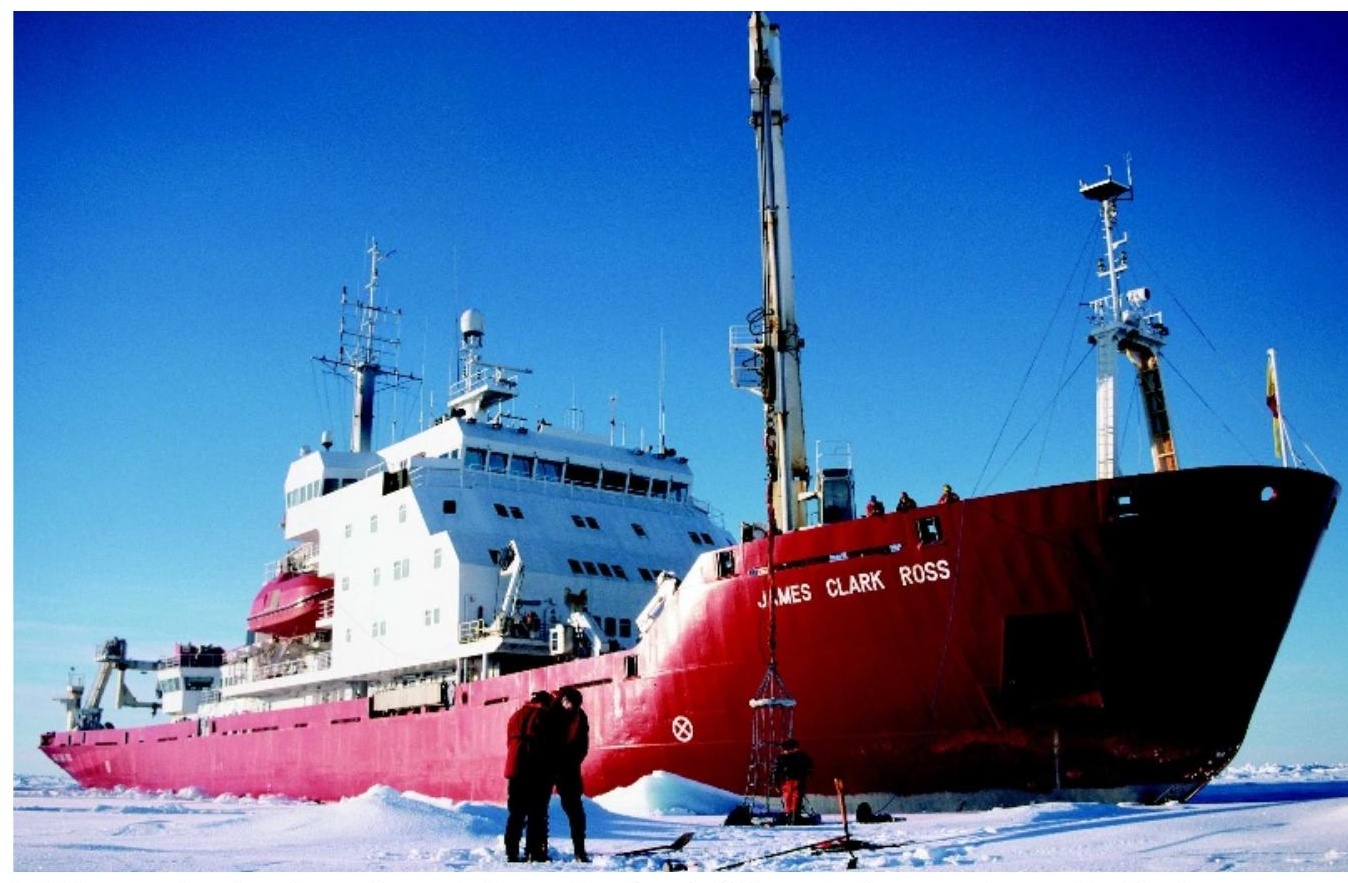

British researchers found more than 250 plumes of methane bubbling up in the sea northwest of Svalbard.

expeditions since the mid-1990s," says Igor Semiletov, who oversees the ISSS methane programme aboard the Russian research ship Jacob Smirnitskyi. "But the data set is extremely limited. Whether what we're seeing in the region is of any relevance for the global climate is mere speculation."

Semiletov says that the scientists did measure higher concentrations of dissolved methane this summer compared to summer

\section{Credit crunch threatens US wind-energy projects}

Wind developers in the United States could be the first among the energy sector to fall victim to the global financial meltdown emanating from Wall Street.

The banking crisis that began with bad loans in the US housing sector has now brought down several commercial banks, one of the world's largest insurance companies and leading investment banks. These last have been particularly important in funding advanced energy technologies (through partnerships with wind developers) and in promoting international carbon markets.

The economic crisis could hit the booming US wind sector first, because the tax incentives designed to promote investment in the technology are meaningless for companies without sufficient profit. Current US law provides wind developers with a tax credit of 2 cents per kilowatt hour. That can add up to millions of dollars annually, but many wind operators do not

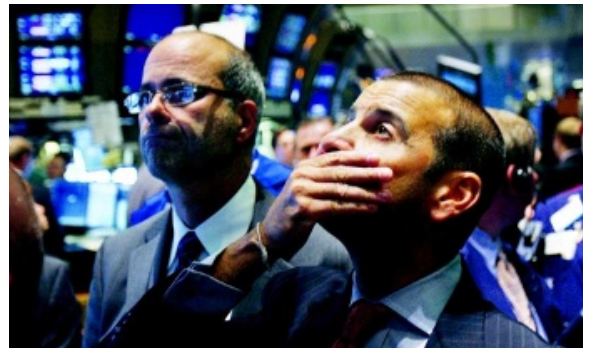

Wall Street's woes may halt the wind-energy boom.

have enough income to take full advantage of that type of tax credit.

Before declaring itself bankrupt on 15 September, US investment bank Lehman Brothers was one of several major firms that invested in wind projects in exchange for the tax credit, which they used to reduce their federal tax bill. The number of firms making such 'tax equity' investments has dropped from more than a dozen to five or six in recent months, says Ethan Zindler, who heads up North American research for the London-based consultancy firm New Energy Finance. "To use the tax credit, you have to have tax exposure, and to have tax exposure you have to have profits."

Congress is fuelling anxiety; it has so far failed to extend the tax credit, which expires at the end of the year. Companies are on track to secure as much as $\$ 8$ billion-10 billion in tax-equity deals - up from $\$ 5.2$ billion in 2007 - assuming they can find the investors. The tax legislation would extend the credit for wind by one year and solar developers would receive an eight-year extension of a separate investment tax credit.

Most expect that the credit will ultimately be extended, even if it is allowed to lapse, but Zindler says that companies are nonetheless rushing to get their deals done now. Forays into carbon markets could become more difficult across the board as banking institutions curb their appetite 
sampling in 2003 and 2004 (N. Shakhova and I. Semiletov J. Mar. Sys. 66, 227-243; 2007). At one ice-covered site in the mere 50 -metre shelf water, they detected methane bubbling at the surface, indicating that at least some of the gas released at the seabed is escaping into the atmosphere before being consumed by bacteria in the water column.

Geologists think that billions of tonnes of methane lie beneath the sub-sea permafrost in some parts of the shallow Siberian shelf, although estimates vary widely. The hydrocarbon - trapped there either as a gas, or bound in solid ice-like structures called methane hydrates - is a remnant from the last ice age when the sea level was about 100 metres lower. The big fear is that the methane could escape as a result of the permafrost becoming porous, possibly from an increased influx of freshwater from the relatively warm Lena River.

"The risk is real," says Hans-Wolfgang Hubberten, a permafrost expert at the Alfred Wegener Institute of Polar and Marine Research in Potsdam, Germany. "But there's no reason to panic. Claims that gas hydrates are on the brink of dissociating in a big way should be taken with a large pinch of salt."

Thermal modelling suggests that the marine permafrost in the region is relatively stable. However, drillings conducted in 2005 revealed that the permafrost may have slightly warmed and thinned (V. Rachold et al. Eos 88, 149-156; 2007). Even so, says Hubberten, it is likely that the observed emissions come from 'new' methane produced by increased bacterial activity in thawing soil, rather than from degradation of ancient gas hydrates.

Methane, air and water samples taken by both teams will now be sent to isotope labs in the Netherlands and the United Kingdom to help determine the source of the methane. Geochemical analysis should also show how much of the gas escapes to the atmosphere, says Westbrook. "The new findings will be useful in helping us assess the history of climate change in the region, and how the methane reservoirs responded to past temperature changes."

Globally, atmospheric methane concentrations increased by 7.5 parts per billion to nearly 1,800 arts per billion during 2007 after almost zero growth since 1999. The upward trend is likely to continue this year, says Ed Dlugokencky, who oversees the methane database run by the National Oceanographic and Atmospheric Administration (NOAA) in Boulder, Colorado. "Our data suggest increased emissions in the Arctic and the tropics," he says. "Both regions were apparently warmer and wetter than average."

Data collected by NOAA at remote sites are usually at least 6 weeks out of date. And NOAA's measurement network in the Arctic is not dense enough to tell if increased methane emissions come from wetlands, permafrost or from gas hydrates on the continental shelves.

Quirin Schiermeier for risk. In particular, says Abyd

Karmali, global head of carbon emissions at Merrill Lynch in London, the development of pilot projects using carbon trading to curb deforestation could get more difficult - at least until an international policy is put in place to guide such investments. Merrill Lynch, which is expected to merge with the Bank of America as a result of the ongoing crisis, is already developing one such project in Indonesia.

Harvard University economist Robert Stavins says that the financial crisis will probably have an impact on the voluntary carbon markets, especially if the economy dives into recession. But regulated markets, such as Europe's carbon trading scheme, will be fine, he says. "Compliance activity by business is immune to business cycles."

Some fear a prolonged economic crisis could make it harder for the United States to enact global-warming legislation owing to concerns about even higher energy prices to come. David Victor, an energy policy expert at Stanford University in Palo Alto, California, says the danger is real: people who are short on cash are less willing to spend money on dealing with distant threats such as global warming.

But Victor believes the fundamental drivers behind the renewed interest in clean energy - high oil prices and concerns about global warming - will remain. "We still have a whole bunch of renewable-energy technologies that are improving their performance," he says. "It's highly likely that people will find capital for these projects." Jeff Tollefson

See Editorial, page 565. 